\title{
Specific Real-time PCR Detection of Monkfish Ingredients
}

\author{
Jijuan $\mathrm{CAO}^{1^{*}}$, Jingquan $\mathrm{LI}^{2}$, Qiuyue $\mathrm{ZHENG}^{1}$ and Junyi $\mathrm{Xu}^{1}$ \\ ${ }^{1}$ Liaoning Entry-Exit Inspection and Quarantine Bureau, Dalian 116001, China \\ ${ }^{2}$ TAKARA BIOTECHNOLOGY(DALIAN) CO.,LTD., Dalian 116600, China
}

Received March 7, 2013; Accepted May 30, 2013

This study was to establish the optimal real-time PCR method for specific identification of puffer fish and monkfish. In this study, we designed the specific primers and probes for fish $12 \mathrm{~s}$ and monkfish cytochrome oxidase subunit I (COI), and used them for specific identification of fish and monkfish. Our results showed that the specific primers and probes for monkfish COI could specifically identify 3 monkfish species, respectively, from total 42 samples of aquatic products. Moreover, the primers and probes for COI were very sensitive to detect $0.01 \%$ Lophius litulon content in the mixed sample of Theragra chalcogramma and Lophius litulon. Therefore, this method is simple, practical, sensitive and specific; is helpful and useful to identify the products of fish and monkfish.

Keywords: monkfish, real-time PCR, detection

\section{Introduction}

The aquatic products are important sources of high protein food, and the business on aquatic products is an important part of globe economy. There are a variety of edible aquatic products, which mainly include 25 populations in international trade (Voorhees et al., 2008). According to U.S. Food and Drug Administration (FDA), over 1700 products are included in the list of aquatic products. As the development of global trade and improvement of seafood processing, some seafood companies usually labeled low value seafood with high value seafood to get high profit, for example, the farm-raised trout was mislabeled with the atlantic salmon, the tilapia and dolphin fishes were mislabeled with the red snapper, etc. (Jacquet and Pauly 2008). According to a 9-year report from National Seafood Inspection Laboratory (NSIL), 37 percent of fish products and 13 percent of other seafood products were mislabeled ${ }^{\mathrm{i})}$. Recent market investigations in Europe and North America showed that the mislabeling rate for raw materials of aquatic products was $15-43 \%$ (Wong and Hanner 2008; Espineira et al., 2009), while the mislabeling rate for red snapper products was as high as $75 \%$ (Marko et al., 2004). Except for economic loss, the mislabeling has raised serious problems in the protection of endangered species, food safety and economic order.

*To whom correspondence should be addressed. E-mail: cjj0909@163.com
Identification of aquatic products has become an important issue for their processing companies. The European Union has implemented regulations to force manufacturers to provide the official commercial and scientific name, the origin, and the production method for all fishery and aquaculture products. The US FDA did not allow the evangelical makeover in aquatic products. Since December, 2011, Canadian Food Inspection Agency and importers employed the DNA testing on seafood to avoid the mislabeling of high value species.

To avoid the fraudulent behavior and ensure food safety, it is necessary to identify the materials of aquatic products. Although it is easy to identify the species of unprocessed aquatic products according to their different appearance and morphological characters, it is necessary to use the DNA testing method to identify the processed aquatic products, such as, minced fish, grilled fish fillet, sashimi, canned fish, fish powder, etc. In the present study, we employed the gene databases from European Molecular Biology Laboratory (EMBL), BOL and FISHTRACE to compare the specific genes for the puffer fish and monkfish. Among candidate genes, we selected the cytochrome oxidase subunit I (COI) as the biomarkers for the monkfish, respectively; while the 12s gene was used the biomarker for fish. The specific primers and probes for above two genes were designed, and the conditions for real-time PCR were optimized to specifically amplify the target gene in different samples. 


\section{Materials and Methods}

Samples Total 42 samples listed in Table 1 were used in this study, which include 3 monkfish species (Lophius litulon, Lophiomus setigerus, Lophius americanus); 9 puffer fishes (Lagocephalus inermis, Lagocephalus lagocephalus, Takifugu fasciatus, Takifugu xanthopterus, Takifugu oblongus, Takifugu rubripes, Gastrophysus gloveri, Gastrophysus lunaris, Gastrophysus spadiceus); 24 other fish species; 1 Tremoctopus violaceus; 1 snow crab (Chionoecetes bairdi); 2 shrimp species; 2 shellfish species. The samples of cooked fish-ball, fish head can, surimi, dried fish floss, roasted fish fillet made from monkfish were supplied by Dalian Ocean Fishery Group Ocean.

DNA extraction DNA from samples was isolated using revised high salt method (Marko et al., 2004). Briefly, samples were grinded with liquid nitrogen and then $150 \mathrm{mg}$ samples were mixed with $400 \mu \mathrm{L}$ TE buffer $(10 \mathrm{mmol} / \mathrm{L}$ Tris$\mathrm{HCl}$ and $1 \mathrm{mmol} / \mathrm{L}$ EDTA), $40 \mu \mathrm{L} 10 \% \mathrm{SDS}$, and $8 \mu \mathrm{L} 20$ $\mathrm{mg} / \mathrm{mL}$ proteinase $\mathrm{K}$. The mixture was digested at $55-65^{\circ} \mathrm{C}$ for $4 \mathrm{~h}$ and mixed with $300 \mu \mathrm{L} 6 \mathrm{~mol} / \mathrm{L} \mathrm{NaCl}$. After centrifugation at $12000 \mathrm{rpm} / \mathrm{min}$ for $30 \mathrm{~min}$, the supernatant was collected and mixed with the same volume of phenol/chloroform/isoamyl alcohol $(25: 24: 1, \mathrm{v} / \mathrm{v})$ for $1 \mathrm{~min}$. The mixture was centrifuged at $12000 \mathrm{rpm} / \mathrm{min}$ for $10 \mathrm{~min}$, then the supernatant was collected and mixed with the same volume of chloroform/isoamyl alcohol (24:1, v/v). The supernatant was collected after centrifugation and mixed with the same volume of isopropyl alcohol and one-tenth volume of $3 \mathrm{M} \mathrm{NaAc}$ for $30 \mathrm{~min}$ on ice, followed by centrifugation at $12000 \mathrm{rpm} /$ min for $10 \mathrm{~min}$. The DNA pellet was washed with $800 \mu \mathrm{L}$ $70 \%$ ethanol and dried out at $56^{\circ} \mathrm{C}$. The DNA was dissolved in $50 \mu \mathrm{L}$ TE buffer and stored at $-20^{\circ} \mathrm{C}$. The concentration from $10 \mu \mathrm{g} / \mathrm{mL}-100 \mu \mathrm{g} / \mathrm{mL}$ and $\mathrm{A} 260 / \mathrm{A} 280$ ratio from 1.7 - 1.9 were taken as the DNA templates of real-time PCR.

Design of primers and probes The specific primers and probes for fish $12 \mathrm{~s}$ and monkfish COI were designed by DNAMAN 8.0 software, and the sequences of primers and probes were listed in Table 2. For design of primers and probes, the consistence of annealing temperature and similarity of GC content were considered. The primers and probes were synthesized by Takara Biotechnology (Dalian) Co., Ltd.

Real-time PCR The PCR was performed in a $25 \mu \mathrm{L}$ reaction mixture containing $2 \mu \mathrm{L}$ DNA $(10 \mu \mathrm{g} / \mathrm{mL}-100 \mu \mathrm{g} /$ $\mathrm{mL}), 1 \mu \mathrm{L}$ forward primer $(10 \mu \mathrm{mol} / \mathrm{L}), 1 \mu \mathrm{L}$ reverse primer $(10 \mu \mathrm{mol} / \mathrm{L}), 1 \mu \mathrm{L}$ probe $(5 \mu \mathrm{mol} / \mathrm{L}), 0.5 \mu \mathrm{L}$ Taq DNA polymerase $(5 \mathrm{U} / \mu \mathrm{L}), 1 \mu \mathrm{L}$ dNTP $(10 \mu \mathrm{mol} / \mathrm{L}), 2.5 \mu \mathrm{L} 10 \times$ PCR buffer, $16 \mu \mathrm{L} \mathrm{dH_{2 }} \mathrm{O}$. The PCR reaction was programmed at 1 cycle of $95^{\circ} \mathrm{C}$ for $10 \mathrm{~s}$ and 40 cycles of $95^{\circ} \mathrm{C}$ for $5 \mathrm{~s}, 52^{\circ} \mathrm{C}$ for $10 \mathrm{~s}$ and $72^{\circ} \mathrm{C}$ for $34 \mathrm{~s}$.

Experiments for specificity and sensitivity of detection method The DNA from all samples were used for the specific detection of fish 12 s and monkfish COI, while the DNA samples from Lophius litulon and Theragra chalcogramma were used for the sensitivity detection of COI primers. For the sensitivity detection experiment, the samples for Lophius litulon and Theragra chalcogramma were minced and dried

Table 1. Name of samples.

\begin{tabular}{clcl}
\hline No. & sample name & No. & sample name \\
\hline 1 & Lophius litulon & 22 & Epinephelus awoara \\
2 & Lophiomus setigerus & 23 & Sardinella longiceps \\
3 & Lophius americanus & 24 & Epinephelus coioides \\
4 & Lagocephalus inermis & 25 & Pseudosciaena crocea \\
5 & Lagocephalus lagocephalus & 26 & Pseudosciaena polyatics \\
6 & Takifugu fasciatus & 27 & pentagonian tooth fish \\
7 & Takifuguxanthopterus & 28 & Reinhardtius hippoglossoides \\
8 & Takifugu oblongus & 29 & Cyprinus carpio \\
9 & Takifugu rubripes & 30 & Tilapia nilotica \\
10 & Gastrophysus gloveri & 31 & Argyrosomus argentatus \\
11 & Gastrophysus lunaris & 32 & Mylopharyngodonpiceus \\
12 & Gastrophysus spadiceus & 33 & Pleuronectes platessa \\
13 & Gadus macrocephalus & 34 & Schilbe intermedius \\
14 & Melanogrammus aeglefinus & 35 & Regalecus glesne \\
15 & Theragra chalcogramma & 36 & Heemisalanx prognathus Regan \\
16 & Scomber scombrus & 37 & Tremoctopus violaceus \\
17 & Clupea harengus L. & 38 & Chionoecetes bairdi \\
18 & Anoplopoma fimbria & 39 & Pandalus borealis \\
19 & Thunnus alalunga & 40 & prawn \\
20 & Oncorhynchus & 41 & Mercenaria mercenaria Linnaeus \\
21 & Epinephelus akaara & 42 & patinopecten yessoensis \\
\hline & &
\end{tabular}


Table 2. Sequences of primers and probes.

\begin{tabular}{lllr}
\hline & \multicolumn{1}{c}{ sene name } & product length (bp) \\
\hline fish 12s & forward primer & 5'-GCCCAATATACGAAAGTAG-3' & 217 \\
& reverse primer & 5'-GGGTTATCGGTTCTAGAA-3' & \\
\multirow{3}{*}{ monkfish COI } & probe & 5'-FAM-CTAAGGCACCGTCAGGTCCT-Eclipse-3' & 162 \\
& forward primer & 5'-CTCTTAGGGGATGACCA-3' & \\
& reverse primer & 5'-CCGATCATAATTGGTATAACC-3' & \\
& probe & 5'-FAM-CGTTATTGTTACCGCACATGCC-TAMRA-3' & \\
\hline
\end{tabular}

out overnight at $80^{\circ} \mathrm{C}$. Then all samples were grinded into powder, and we added different ratios $(100 \%, 10 \%, 1 \%, 0.5 \%$, $0.1 \%, 0.01 \%, 0.001 \%(\mathrm{w} / \mathrm{w}))$ of the Lophius litulon powder into the Theragra chalcogramma powder. The DNA from mixed samples was extracted and used as the template for the sensitivity detection of COI primers by real-time PCR. All experiments were repeated for 6 times.

\section{Results}

Amplification of fish 12s by real-time PCR All samples were used to amplify the fish $12 \mathrm{~s}$ using specific primers and probe and result was shown in Fig. 1. Using real-time PCR, the growth curve for fish 12s was obtained in all 36 fish samples, while negative result was found in water control and DNA samples from 6 other seafood products including Tremoctopus violaceus, Chionoecetes bairdi, Pandalus borealis, prawn, Mercenaria mercenaria Linnaeus, and patinopecten yessoensis. These results suggest that the primers for fish $12 \mathrm{~s}$ are good for identifying the fish species and their processing products.

Specific amplification of monkfish COI using real-time $P C R \quad$ The specific primers and probe for monkfish COI were used to identify the monkfish species in all 42 samples and results were shown in Fig. 2. We found the growth curve for COI was only detected in DNA samples from 3 monkfish species (Lophius litulon, Lophiomus setigerus, Lophius americanus), while negative results were obtained from 39 other DNA samples and water empty control. These data suggest that the primers and probe for $\mathrm{COI}$ are specific to identify the monkfish species. All the specific tests were repeated 6 times. Meanwhile, the repeatability of results were all fine.

Sensitivity of detection method Since the processing procedure may affect the DNA quality of fish samples and some retailers may have fraudulent behavior in some processed aquatic products by mixing low value seafood with high value seafood, these situations need a sensitive method to identify the exact components of processed products. To

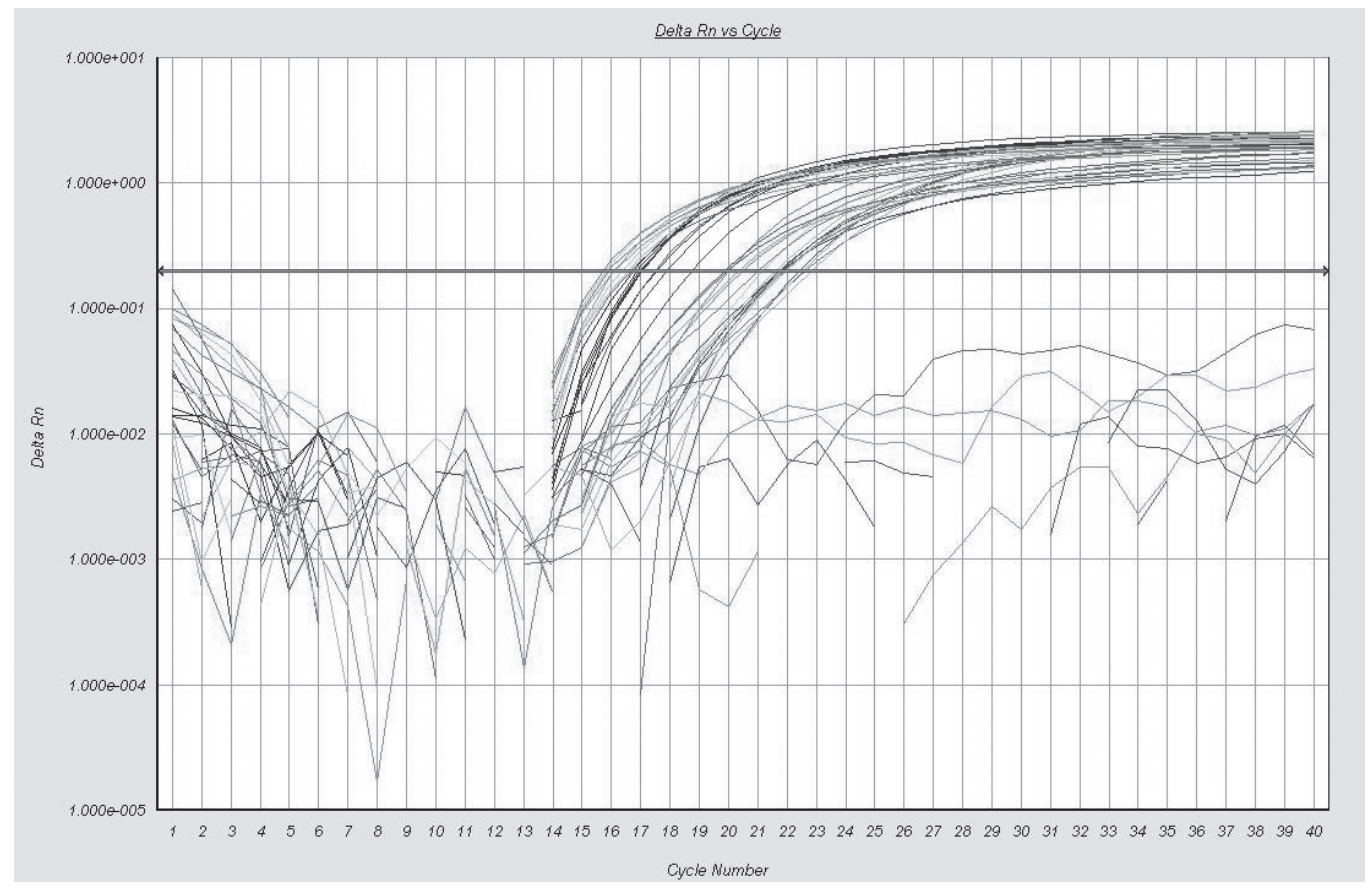

Fig. 1. Illustration for specific amplification of fish $12 \mathrm{~s}$ using real-time PCR. 


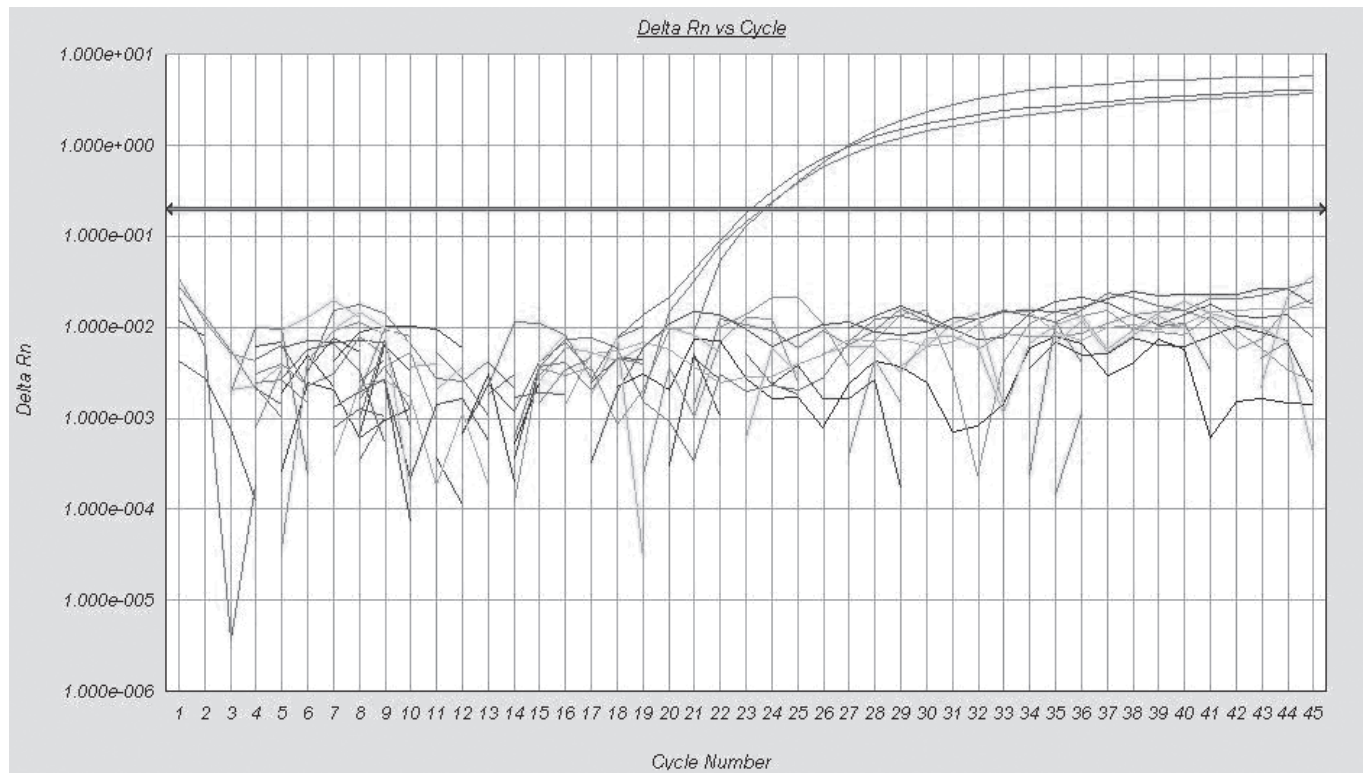

Fig. 2. Specific amplification of monkfish COI DNA fragment using real-time PCR.

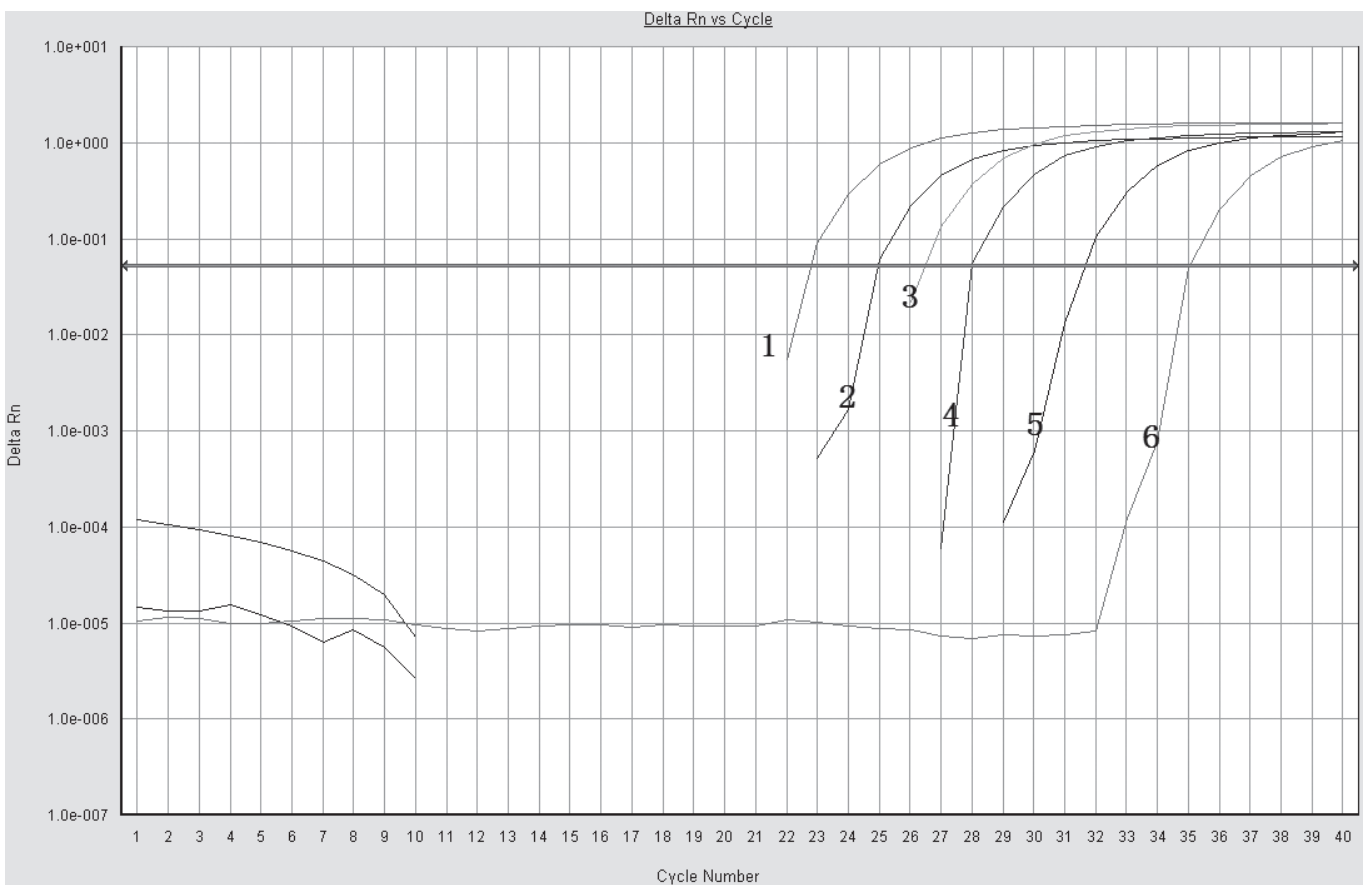

Fig. 3. Sensitivity of real-time PCR method for monkfish COI.

1, 100\% Lophius litulon powder; 2, 10\% Lophius litulon powder; 3, 1\% Lophius litulon powder; 4, 0.5\% Lophius litulon powder; 5, 0.1\% Lophius litulon powder; 6, 0.01\% Lophius litulon powder.

identify the sensitivity of this method, here we added different ratios $(100 \%, 10 \%, 1 \%, 0.5 \%, 0.1 \%, 0.01 \%, 0.001 \%)$ of Lophius litulon powder into the Theragra chalcogramma powder and detected the DNA of monkfish COI in different mixed samples. As shown in Fig. 3, we found the specific band of monkfish COI was detected in all mixed samples except $0.001 \%$ Lophius litulon powder, suggesting that this method for monkfish COI is very sensitive to detect as low as $0.01 \%$ Lophius litulon powder in the mixed powder. From the DNA extraction to real-time PCR amplification, all the specific tests were repeated 6 times. Only $0.001 \%$ monkfish powder appeared positive results 1 times, and negative results 5 times. The test results of other samples of different concentration were all positive.

Real food testing The food made by fish is more delicious and convenient to eat. In order to verify the effectiveness of this method, the samples of cooked fish-ball, fish head can, surimi, dried fish floss, roasted fish fillet made from 
monkfish were used as test specimens. All of the results were positive, which demonstrated the effectiveness of this method.

\section{Discussion}

Because the authentication of aquatic products is helpful to maintain fair trade and protect food safety and endangered species, many researchers work in this field and have developed some applicable methodes. Espineira et al. (2008a, 2008b, 2009) developed a method for the authentication of sapper, tilapia, scombroid, anglerfish, flatfish and salmon, by means of FINS (Forensically Informative Nucleotide Sequencing) technique, which is based on PCR followed by a phylogenetic analysis. DNA barcoding project is an important part of FINS technology, which is a global program that uses the COI sequences to identify the species. To date, this method can accurately identify $98 \%$ of marine fish species and $93 \%$ of freshwater fish species (Ward et al., 2009). Some researchers used the PCR-RFLP (restriction fragment length polymorphism) technology to identify the processed products of salmon, trout, anchovy and puffer fish (Rasmussen et al., 2009; Rea et al., 2009; Hsieh et al., 2010), while the PCR-SSCP (single strand conformation polymorphism) method was used to identify the species of salmon, sardine, eel, tunny, skipjack, sturgeon, etc (Rehbein et al., 1997; Rehbein et al., 1999; Rehbein et al., 2002). In addition, Lowenstein et al. (2009) used the RAPD (random amplification of polymorphic DNA) technology for genetic analysis and identification. Recent studies reported that the multiplex PCR method was successfully used to identify shark, flatfish, skipjack, mackerel, salmon and trout (Lin and Wang, 2008; Mendonca et al., 2010; Rasmussen Hellberg et al., 2010; Catanese et al., 2010). In 2002, Taylor et al. developed a multiplex, single tube (TaqMan) PCR assay for the identification of three commercially important gadoid species, the cod (Gadus morhua L.), the haddock (Melanogrammus aeglefinus L.) and the whiting (Merlangius merlangus L.) (Taylor et al., 2002). After that, researchers successfully employed TaqMan MGB probes to identify eel, tunny, salmon and trout, and Taqman LNA probes for identifying sea bream and American redfish (Itoi et al., 2005; Lopez and Pardo 2005; Mort et al., 2008). In 2004, BioMérieux announced the launch of FoodExpert-ID that is the first high-density DNA chip for food and animal feed testing and can detect the raw materials and processed products from 33 different species of vertebrate, including 15 fish species. Chisholm et al. employed the bioMerieux FoodExpert-ID system to identify the pecies of food products and verified its applicability (Chisholm et al., 2008). In addition, Kochzius et al. created a "Fish Chip" to differentiate 11 important fish species from European seas (Kochzius et al., 2008).
Each method has its own advantages and disadvantages: PCR sequencing is not remarkable in speed and cost; RCPRFLP is time-consuming due to many analysis steps; high sensitivity of SSCP requires high repeatability and consistence of experiments; the disadvantage of PCR-RAPD is its repeatability, which disadvantage is more severe when the DNA sample is less or degraded (Rego et al., 2002). In addition, the AFLP method is very time-consuming so as to affect its large-scale application. Compare to other methods, the DNA chip is very costly and slow to analyze samples. Although the specific primers for specific species limit the application of real-time PCR method to general species, this method has the characteristics of low cost and easy manipulation, is extensively used for identifying the specific species from mixed samples.

It is difficult to differentiate the fillet and fish paste made from monkfish by morphological character. To ensure food safety, it is very imperative to select the appropriate gene and develop a practical and feasible real-time PCR method to identify the products of monkfish. In the present study, the real-time PCR methodes are very specific, sensitive, simple, quick, and practical, and provide effective tools for authentication of the monkfish species.Acknowledgments

This study was supported by National High-tech Research \& Development Program (2011AA00807) and the special fund from National Public Science and Technology Research (2007GYJ036).

\section{References}

Catanese, G., Manchado, M., Fernandez-Trujillo, A. and Infantem C. (2010). A multiplex-PCR assay for the authentication of mackerels of the genus Scomberin processed fish products. Food Chem., 122, 319-326.

Chisholm, J., Conyers, C.M. and Hird, H. (2008). Species identification in food products using the bioMerieux FoodExpertIDsystem. Eur. Food Res. Technol., 228, 39-45.

Espineira, M., Gonzalez-Lavin, N., Vieites, J.M. and Santaclara, F.J. (2008a). Development of a method for the genetic identification of flatfish species on the basis of mitochondrial DNA sequences. $J$. Agric. Food Chem., 56, 8954-8961.

Espineira, M., Gonzalez-Lavin, N., Vieites, J.M. and Santaclara, F.J. (2008b). Authentication of anglerfish species (Lophiusspp) by means of polymerase chain reaction restriction fragment length polymorphism (PCR-RFLP) and forensically informative nucleotide sequencing (FINS) methodologies. J. Agric. Food Chem., 56, 10594-10599.

Espineira, M., Gonzalez-Lavin, N., Vieites, J.M. and Santaclara, F.J. (2009). Development of a method for the identification of scombroid and common substitute species in seafood products by FINS. Food Chem., 117, 698-704. 
Hsieh, C.H., Chang, W.T., Chang, H.C., Hsieha, H.S., Chunga, Y.L. and Hwang, D.F. (2010). Puffer fish-based commercial fraud identification in a segment of cytochrome $b$ region by PCR-RFLP analysis. Food Chem., 121, 1305-1311.

Itoi, S., Nakaya, M., Kaneko, G., Kondo, H., Sezaki, K. and Watabe, S. (2005). Rapid identification of eels Anguilla japonica and Anguilla anguilla by polymerase chain reaction with single nucleotide polymorphism-based specific probes. Fisheries Sci., 71, 1356-1364.

Jacquet, J.L. and Pauly, D. (2008). Trade secrets: renaming and mislabeling of seafood. Marine Policy, 32, 309-318.

Kochzius, M., Nolte, M., Weber, H., Silkenbeumer, N., Hjorleifsdottir, S., Hreggvidsson, G., Marteinsson, V., Kappel, K., Planes, S., Tinti, F., Magoulas, A., Garcia Vazquez, E., Turan, C., Hervet, C., Campo Falgueras, D., Antoniou, A., Landi, M. and Blohm, D. (2008). DNA microarrays for identifying fishes. Marine Biotechnol., 10, 207-217.

Lin, W.F.H. and Wang, D.F. (2008). Application of species-specific PCR for the identification of dried bonito product (Katsuobushi). Food Chem., 106, 390-396.

Logan, C.A., Alter, S.E., Haupt, A.J., Tomalty, K. and Palumbi, S.R. (2008). An impediment to consumer choice: overfished species are sold as Pacific red snapper. Biol. Conser., 141, 1591-1599.

Lopez, I. and Pardo, M.A. (2005). Application of relative quantification TaqMan real-time polymerase chain reaction technology for the identification and quantification of Thunnus alalunga and Thunnus albacares. J. Agric. Food Chem., 53, 4554-4560.

Lowenstein, J.H., Amato, G. and Kolokotronis, S.O. (2009). The real maccoyii: identifying tuna sushi with DNA barcodes-contrasting characteristic attributes and genetic distances. PLoS One. 4, e7866.

Marko, P.B., Lee, S.C., Rice, A.M., Gramling, J.M., Fitzhenry, T.M., McAlister, J.S., Harper, G.R. and Moran, A.L. (2004). Fisheries: mislabeling of a depleted reef fish. Nature, 430, 309-310.

Mendonca, F.F., Hashimoto, D.T., De-Franco, B., Porto-Foresti, F., Gadig, O.B.F., Oliveira, C. and Foresti, F. (2010). Genetic identification of lamniform and carcharhiniform sharks using multiplex-PCR. Conservation Genetics Resoures, 2, 31-35.

Mort, B.K., Graham, W.M. and Hernandez, F.J. (2008). Multiplex assay to identify eggs of three fish species from the $n$ hern Gulf of Mexico, using locked nucleic acid Taqman real-time PCR probes. Aquat. Biol., 4, 65-73.

Rasmussen Hellberg, R.S., Morrissey, M.T. and Hanner, R.H. (2010). A multiplex PCR method for the identification of com- mercially important salmon and trout species (Oncorhynchus and Salmo) in North America. J. Food Sci., 75, C595-606.

Rasmussen, R.S., Morrissey, M.T. and Hebert, P.D.N. (2009). DNA barcoding of commercially important salmon and trout species (Oncorhynchus and Salmo) from North America. J. Agric. Food Chem., 57, 8379-8385.

Rea, S., Storani, G., Mascaro, N., Stocchi, R. and Loschi, A.R. (2009). Species identification in anchovy pastes from the market by PCR-RFLP technique. Food Control, 20, 515-520.

Rego, I., Martinez, A., Gonzalez-Tizon, A., Vieites, J., Leira, F. and Méndez, J. (2002). PCR technique for the identification of mussel species. J. Agric. Food Chem., 50, 1780-1784.

Rehbein, H., Sotelo, C.G. and Perez-Martin, R.I. (2002). Differentiation of raw or processed eel by PCR-based techniques: restriction fragment length polymorphism analysis (RFLP) and single strand conformation polymorphism analysis (SSCP). Eur. Food Res. Technol., 214, 171-177.

Rehbein, H., Kress, G. and Schmidt, T. (1997). Application of PCRSSCP to species identification of fishery products. J. Sci. Food Agric., 74, 35-41.

Rehbein, H., Mackie, I.M., Pryde, S., Gonzales-Soteloc, C., Medinac, I., Perez-Martinc, R., Quinteirod, J. and Rey-Mendez, M. (1999). Fish species identification in canned tuna by PCR-SSCP: validation by a collaborative study and investigation of intraspecies variability of the DNA-patterns. Food Chem., 64, 263268.

Taylor, M.I., Fox, C., Rico, I. and Rico, C. (2002). Species-specific TaqManprobes for simultaneous identification of (Gadusmorhua L.), haddock (Melanogrammusaeglefinus L.) and whiting (Merlangiusmerlangus L.). Mol. Ecol. Notes., 2, 599-601.

Voorhees, D.V. (2008). Current Fisheries Statistics. No. 2008. Fisheries of the United States, National Marine Fisheries Service, Office of Science and Technology, pp. 39-55

Ward, R.D., Hanner, R. and Hebert, P.D.N. (2009). The campaign to DNA barcode all fishes, FISH-BOL. J. Fish Biol., 74, 329-356.

Wong, E.H.K. and Hanner, R.H. (2008). DNA barcoding detects market substitution in North American seafood. Food Res. Int., 41, 828-837.

\section{URL cited}

i) Tennyson, J.M., Winters, K.S. and Powell, K. (2008). A fish by any other name: a report on species substitution. http://fshn.ifas. ufl.edu/seafood/sst/ 22ndAnn/file08.pdf [EB/OL] (2008-05-13) [2012.02.22]. 